\title{
Tumour growth and resistance to gemcitabine of pancreatic cancer cells are decreased by AP- $2 \alpha$ overexpression
}

\author{
N Jonckheere ${ }^{1,2,5}$, V Fauquette ${ }^{1,5}$, L Stechly ${ }^{1,3}, \mathbf{N}$ Saint-Laurent ${ }^{4}$, S Aubert $^{1,2,3}$, C Susini $^{4}$, G Huet $^{1,2,3}$, \\ N Porchet ${ }^{1,2,3}$, I Van Seuningen ${ }^{1,2}$ and P Pigny*, , 2,3
}

'INSERM, U837, Place de Verdun, 59045 Lille cedex, France; ${ }^{2}$ Université de Lille 2, Centre de Recherche Jean-Pierre Aubert, Place de Verdun, 59045 Lille cedex, France; ${ }^{3}$ Centre de Biologie et Pathologie, CHRU, 59037 Lille cedex, France; ${ }^{4}$ INSERM U858, Institut de Médecine Moléculaire de Rangueil, BP 84225, 31432 Toulouse Cedex 4, France

\begin{abstract}
BACKGROUND: Activator protein-2 $\alpha$ (AP- $2 \alpha)$ is a transcription factor that belongs to the family of AP-2 proteins that have essential roles in tumorigenesis. Indeed, AP- $2 \alpha$ is considered as a tumour-suppressor gene in different tissues such as colonic, prostatic or breast epithelial cells. Moreover, AP- $2 \alpha$ also participates in the control of colon and breast cancer cells sensitivity towards chemotherapeutic drugs. Despite its potential interest, very few data are available regarding the roles of AP- $2 \alpha$ in pancreatic cancer. METHODS: We have developed a stable pancreatic CAPAN-I cell line overexpressing AP-2 $\alpha$. Consequences of overexpression were studied in terms of in vivo cell growth, gene expression, migration capacity and chemosensitivity.

RESULTS: In vivo tumour growth of CAPAN-I cells overexpressing AP- $2 \alpha$ was significantly decreased by comparison to control cells. An altered expression pattern of cell cycle-controlling factors (CDK-4, CDK-6, cyclin-GI, p27 kipl and p57 ${ }^{\text {kip2 }}$ ) was observed in AP- $2 \alpha$-overexpressing clones by microarrays and western blot analysis. Promoter activity and ChIP analysis indicated that AP- $2 \alpha$ induces $p 27^{\text {kip I }}$ protein levels by direct binding to and transactivation of its promoter. Moreover, AP- $2 \alpha$ overexpression increased the chemosensitivity of CAPAN-I cells to low doses of gemcitabine and reduced their in vitro migration capacity.

CONCLUSION: Our data suggested that AP- $2 \alpha$ overexpression could be exploited to decrease in vivo tumour growth of pancreatic cancer cells and to increase their sensitivity to gemcitabine.

British Journal of Cancer (2009) I 01, 637-644. doi:I0.1038/sj.bjc.6605 I90 www.bjcancer.com
\end{abstract}

(c) 2009 Cancer Research UK

Keywords: mucin; AP-2 $\alpha$; gemcitabine; pancreatic cancer; cell cycle

Activator protein-2 $\alpha$ (AP-2 $\alpha$ ) belongs to the AP-2 family of transcription factors that comprises five members encoded by separate genes. All AP-2 proteins share two functional domains, that is, a proline/glutamine-rich transactivation domain and a helix-turn-helix DNA-binding domain. This last one allows AP-2 proteins to bind to GC-rich consensus regions located in the promoters of their target genes (Eckert et al, 2005). As recently reviewed (Orso et al, 2008), AP-2 proteins have relevant roles in tumorigenesis by regulating some key genes involved in cell proliferation (ErbB-2,c-myc proto-oncogenes), cell cycle regulation (CDKN1A), cell adhesion and invasion (MMP-2, MMP-9, $P A R-1$ and MUC18). Moreover, several lines of evidence suggested that AP- $2 \alpha$ might behave as a tumour-suppressor gene (TSG) in several tissues. For example, loss of AP- $2 \alpha$ expression was reported in metastatic melanoma cells (Tellez et al, 2003), in prostate (Ruiz et al, 2001) and colon cancer cells (Schwartz et al, 2007). In breast cancer cells, contrasting results were reported in the literature. Earlier studies suggested that AP-2 proteins promote the malignant potential of breast cancer cells by transactivating the promoters of ErbB-2 and ErbB-3 (Bosher et al, 1996). However, recent data using $s h$ RNA to knockdown AP- $2 \alpha$ expression in breast cancer cell lines showed that AP- $2 \alpha$ inhibits tumour growth both

\footnotetext{
*Correspondence: Professor P Pigny; E-mail: pascal.pigny@inserm.fr

${ }^{5}$ These authors contributed equally to this work

Revised I5 June 2009; accepted 17 June 2009
}

in vitro and in vivo (Orso et al, 2008). Besides being a potential TSG, AP- $2 \alpha$ also participates in the control of colon and breast cancer cells sensitivity towards chemotherapeutic drugs (Wajapeyee et al, 2005). Despite its potential interest, very few data are available regarding the roles of AP- $2 \alpha$ in pancreatic cancer (Vernimmen et al, 2003). Recently we showed that, in human pancreas (Fauquette et al, 2007), AP- $2 \alpha$ was expressed by almost $66 \%$ of non-tumoural ductal cells and endocrine cells by immunohistochemistry, whereas its expression was decreased to only $5.5 \%$ of pancreatic ductal adenocarcinoma (PDAC). We also showed that the expression of AP- $2 \alpha$ was mutually exclusive with that of the human epithelial mucin, MUC4, which is a specific marker of this condition, being expressed in $83 \%$ of the PDAC samples. These data suggested that AP- $2 \alpha$ might also behave as a TSG in human PDAC.

Interestingly, PDAC corresponds to the most frequent histological form of pancreatic cancer, which remains a devastating condition with only $3 \%$ of patients alive at 5 years after diagnosis. This is because of the inability to detect cancer at onset, its aggressiveness and the lack of effective therapies (Schneider et al, $2005)$. Indeed, at the time of diagnosis, more than $80 \%$ of patients have locally advanced or incurable metastatic disease. Gemcitabine, the only approved drug for the treatment of pancreatic cancer, offers a partial response in $<6 \%$ of the patients (Chua and Cunningham, 2006). Our interest first focused on the epithelial mucin, MUC4, in this disease because it is not expressed by normal pancreatic tissue but is gradually expressed during pancreatic 
carcinogenesis from the premalignant lesions, that is, pancreatic intraepithelial neoplasia (PanIN) type 1 (which are MUC4-positive in $17 \%$ of the cases) to PDAC (Swartz et al, 2002). Moreover, experimental data showed that the knockdown of MUC4 expression by shRNA in HPAF cancer cell line is accompanied by a significant decrease of cell proliferation in vitro, tumour growth and incidence of metastasis in vivo (Chaturvedi et al, 2007), suggesting that MUC4 could have an important role in pancreatic carcinogenesis. Indeed, MUC4 forms a protein complex with the ErbB-2 receptor in human pancreatic cancer cells and modulates its downstream signalling (Chaturvedi et al, 2008).

To decipher the molecular mechanisms that govern MUC4 expression in pancreatic cancer, we previously characterised its promoter and identified several consensus binding sites for AP-2 transcription factor (Perrais et al, 2001). In our recent study, we showed that AP- $2 \alpha$ is a trans-repressor factor of MUC4 promoter in two well-differentiated pancreatic cancer cell lines that expressed MUC4. We thus produced several stable clones derived from CAPAN-1 cell line that stably overexpressed AP- $2 \alpha$. These clones are characterised by a strong downregulation of MUC4 along with a strong upregulation of the cdk inhibitor, p27 $7^{\text {kip1 }}$ (Fauquette et al, 2007). Interestingly, we also showed that these clones exhibited a significant decrease of in vitro cell growth and cell invasion. In this study, our aims were to evaluate whether AP- $2 \alpha$ overexpression could modulate the phenotype of the parental CAPAN-1 cell line in terms of chemosensitivity, migration capacity, pattern of gene expression, topography of epithelial markers expression and in vivo cell growth.

\section{MATERIALS AND METHODS}

\section{Total cellular extract preparation and western blotting}

After scraping, the cells were pelleted, washed with $1 \times$ phosphatebuffered saline (PBS) and incubated in lysis buffer (50 mM Tris$\mathrm{HCl} \mathrm{pH} \mathrm{7.5,} \mathrm{containing} 150 \mathrm{~mm} \mathrm{NaCl}, 1 \%(\mathrm{w} / \mathrm{v}) \mathrm{NP} 40,5 \mathrm{~mm}$ sodium fluoride, $5 \mathrm{~mm}$ sodium orthovanadate, $0.25 \%$ (w/v) sodium deoxycholate and a cocktail of protease inhibitors) for $30 \mathrm{~min}$ at $4^{\circ} \mathrm{C}$. After $10 \mathrm{~min}$ of centrifugation at $13210 \mathrm{~g}\left(4^{\circ} \mathrm{C}\right)$, the supernatant (total extract) was stored at $-80^{\circ} \mathrm{C}$. Western blots were carried out as previously described (Fauquette et al, 2005). Peroxydase-conjugated secondary antibodies were used and immunoreactive bands were visualised using the West Pico chemoluminescent substrate (Perbio, Brebières, France).

\section{Confocal microscopy}

Cells were fixed with $4 \%$ paraformaldehyde (w/v) for $20 \mathrm{~min}$, quenched for $20 \mathrm{~min}$ with $50 \mathrm{mM} \mathrm{NH}_{4} \mathrm{Cl}$ in PBS and permeabilised with $0.2 \%$. (w/v) saponin in PBS for $20 \mathrm{~min}$. The saturation step was performed for $20 \mathrm{~min}$ in PBS containing $1 \%$ bovine serum albumin (BSA) and $0.2 \%$ saponin (w/v). Cells were then incubated overnight with different primary antibodies diluted in PBS containing $1 \%$ BSA and $0.2 \%$ saponin. After PBS washings, cells were incubated for $2 \mathrm{~h}$ with secondary fluorescein isothiocyanate or tetra methyl rhodamine isothiocyanate (TRITC)-conjugated antibodies. Laser microscopy analysis was carried out using a Leica instrument (Model TCS-NT) with a $63 \times 1.32$ Plan-Apochromat oil-immersion objective lens (Leica Microsystems, Cedex, France). Files of microphotographs were processed with Adobe Photoshop 5.0. (San Jose, CA, USA).

\section{Antibodies}

For confocal microscopy analysis, monoclonal antibodies against MUC1 (214D4) and MUC4 (m8G7) were used. These were kind gifts from J Hilkens (The Netherlands Cancer institute, Amster- dam, The Netherlands) and SK Batra (Eppley Cancer Institute, Omaha, NE, USA), respectively. For western blotting, membranes were probed with antibodies against ErbB-2 (NCL CB11 from Novo Castra, dilution 1/250), cyclin-D1 (sc-718, dilution 1/500), cyclinG1 (sc-7865, dilution 1/500), cdk-4 (sc-601, dilution 1/1000), cdk-6 (sc-177, dilution 1/1000), p57 (sc-1040, dilution 1/2000, all from Santa Cruz Biotechnology Inc., Heidelberg, Germany) or $\beta$-actin (A5441, dilution 1/5000 from Sigma, St Quentin Fallerier, France).

\section{Subcutaneous (s.c.) xenografts}

CAPAN-1 cells and its deriving clones were injected s.c. $\left(4 \times 10^{6}\right.$ cells in $0.4 \mathrm{ml}$ of RPMI) into athymic female nude mice that were bred and maintained in pathogen-free conditions (six mice per cell type). Tumour development was followed periodically. The tumour volume $\left(\mathrm{mm}^{3}\right)$ was determined by the equation $\mathrm{V}=\mathrm{W}^{2} . \mathrm{L} / 2$, in which $\mathrm{W}$ corresponds to the width (in $\mathrm{mm}$ ) and $\mathrm{L}$ to the tumour length (in $\mathrm{mm}$ ). Mice were killed at days 22 or 28 after inoculation. All animal procedures were in accordance with the guidelines of the animal care committee. For each subcutaneous tumour, one tissue fragment was fixed in formalin before inclusion into paraffin.

\section{Microarrays}

To monitor gene expression in response to AP- $2 \alpha$ overexpression, RNA was prepared from C5, $\alpha 27$ and $\alpha 42$ clones using Macherey Nagel NucleoSpin RNA II kit (Hoerdt, France). RNA quality was checked using the Agilent 2100 Bioanalyser (IFR 114 facility, Agilent Technologies, Massy, France). The complementary labelled RNA probe was synthesised using the Truelabeling AMP kit (SuperArray Bioscience, SA Biosciences, TebuBio, Le Perrayen-Yvelines, France) and biotin-16-UTP (Roche, Meyba, France), and hydridised with the cell cycle OligoGEArray (SuperArray Bioscience). Signal was generated using the ECF substrate (GE Health care, Orsey, France), and detected using the storm system, and analysed using the GEArray Expression Analysis Suite (SuperArray Bioscience) with normalisation with housekeeping genes.

\section{Transient transfections}

The pancreatic cancer cells, CAPAN-1, were transfected with $0.5 \mu \mathrm{g}$ of the pGVB2 basic vector carrying promoter elements of $\mathrm{p} 27^{\mathrm{kip} 1}$ gene $(C D K N 1 B)$ upstream of the luciferase gene (kind gift from $\mathrm{Pr}$ T Sakai, Kyoto Prefectural University of medicine, Kyoto, Japan) as previously described (Fischer et al, 2005), and $0.25 \mu \mathrm{g}$ of an expression vector encoding AP- $2 \alpha$ (pRSV-AP-2 gift from Dr $\mathrm{H}$ Hurst, ICRF Molecular Oncology Unit, London, UK). Results were expressed as fold induction relative to the cotransfection performed in the presence of the corresponding empty expression vector, as previously described (Fauquette et al, 2005). Two putative AP-2-binding sites located at -316 and -244 of CDKN1B promoter were mutated separately using the QuickChange Sitedirected mutagenesis kit (Stratagene, Agilent Technologies, Massy, France) as previously described (Fauquette et al, 2005). The -316 site was mutated from $5^{\prime}$-CCGCGGGC- $3^{\prime}$ to $5^{\prime}$-TAGCGAAT- $3^{\prime}$ and the -244 site from $5^{\prime}$-GCCCTCCCG- $3^{\prime}$ to $5^{\prime}$-AATCTCTAA- $3^{\prime}$. The mutated plasmid DNA was sequenced on both strands before being used in cell transfection experiments.

\section{ChIP assay}

The Chromatin Immuno Precipitation (ChIP) assay was carried out as previously described (Fauquette et al, 2007) using $6 \mu \mathrm{g}$ of an anti-AP- $2 \alpha$ antibody (C18 from Santa Cruz Biotechnology) or a normal rabbit IgG (Upstate, Millipore, St Quentin en Yvelines, France). For the PCR, two pairs of primers were designed to selectively amplify a distal $(-610 /-479)$ or a proximal region 
$(-426 /-20)$ of the $C D K N 1 B$ promoter. PCR was carried out in a $50 \mu \mathrm{l}$ volume containing $50 \mathrm{ng}$ of DNA, $5 \mathrm{U}$ of AmpliTaq Gold (Applied Biosystems, Courtaboeuf, France), $0.5 \mu \mathrm{M}$ of each primer, $2.5 \mathrm{mM} \mathrm{MgCl}_{2}$ and $5 \%$ dimethylsulphoxide using the following protocol: $3 \mathrm{~min}$ at $95^{\circ} \mathrm{C}$ followed by $\left(\left(95^{\circ} \mathrm{C}\right) 15 \mathrm{~s},\left(\mathrm{X}_{1} 1^{\circ} \mathrm{C}\right.\right.$ per cycle $)$ $\left.15 \mathrm{~s},\left(72^{\circ} \mathrm{C}\right) 15 \mathrm{~s}\right) \times 10,\left(\left(95^{\circ} \mathrm{C}\right) 15 \mathrm{~s},\left(\mathrm{X}_{2}^{\circ} \mathrm{C}\right) 15 \mathrm{~s},\left(72^{\circ} \mathrm{C}\right) 15 \mathrm{~s}\right) \times 32$ and $72^{\circ} \mathrm{C}$ for $5 \mathrm{~min}$, where $\mathrm{X}_{1}$ and $\mathrm{X}_{2}$ were $\left(58^{\circ} \mathrm{C}, 48^{\circ} \mathrm{C}\right)$ for the distal region and $\left(64^{\circ} \mathrm{C}, 55^{\circ} \mathrm{C}\right)$ for the proximal region, respectively. PCR products were analysed on a $0.8 \%$ agarose gel.

\section{Effects of gemcitabine in vitro}

Gemcitabine was a kind gift from Eli Lilly (Indianapolis, IN, USA). Cells were plated in 6-well sterile plates at a $10^{5}$ cells per well and were allowed to attach overnight. Cells were treated either with $0.001-100 \mu \mathrm{g} \mathrm{ml}^{-1}$ of gemcitabine for $1 \mathrm{~h}$ as previously described (Giovannetti et al, 2004). After drug treatments were completed, the cytotoxicity was expressed as the percentage of surviving cells relative to untreated cultures. C5 mock cells were used as control cell. Two independent experiments in triplicate were carried out.

\section{Flow cytometry}

Cells were treated with low doses of gemcitabine $\left(0,0.1\right.$ or $\left.1 \mu \mathrm{g} \mathrm{ml}^{-1}\right)$ during $24 \mathrm{~h}$ before being harvested by trypsinisation, and then resuspended in PBS. The cells were fixed by addition of $1 \mathrm{ml}$ of $70 \%$ ethanol and incubation on ice for $30 \mathrm{~min}$. Cells were then washed with PBS, treated for $5 \mathrm{~min}$ by RNAse A $\left(100 \mu \mathrm{g} \mathrm{ml}^{-1}\right)$ and finally stained with propidium iodide $\left(50 \mu \mathrm{g} \mathrm{ml}^{-1}\right)$ for $30 \mathrm{~min}$. Cell analysis was carried out on a Beckman Coulter EPICS XL3-MCL (Villepinte, France) using the Wincycle software (Phoenix Flow Systems, San Diego, CA, USA).

\section{Migration assay}

Cell migration properties of the different clones were assessed using 24-well Boyden chambers (BD Bio Coat Insert $8 \mathrm{pm}$ ) with $8.0 \mu \mathrm{m}$ pores (BD Biosciences, Le Pont de Claix, France) following the manufacturer protocol. Briefly, $15 \%$ foetal bovine serum was used as chemoattractant in the lower chamber. A total of $5 \times 10^{4}$ cells were plated in the top chamber and were incubated for $48 \mathrm{~h}$. After staining with Diffquick (Médiane Diagnostics, Plaisir, France), cells on the lower surface were counted on microscopy at $\times 100$ magnification. Eight random vision fields were counted and the experiment was repeated four times.

\section{Statistical analysis}

Data are presented as mean \pm s.d. Differences in the mean of two samples were analysed using Student's $t$-test with differences $<0.05$ considered significant.

\section{RESULTS}

\section{Expression and localisation of MUC1 and MUC4 in CAPAN-1 clones overexpressing AP- $2 \alpha$}

We previously produced stable clones deriving from CAPAN-1 cell line that overexpressed moderate (clones $\alpha 42$ and $\alpha 45$, one arrow on Figure 1A) or high levels ( $\alpha 27$ and $\alpha 38$, two arrows on Figure 1A) of AP- $2 \alpha$, and consequently exhibited a partial to complete inhibition of MUC4 expression, respectively (Fauquette et al, 2007). To further characterise the pattern of expression of these clones, levels of expression of ErbB-2 (the putative MUC4 receptor) and of the membrane-bound mucin MUC1 were determined by western blotting. As previously shown with MUC4
A

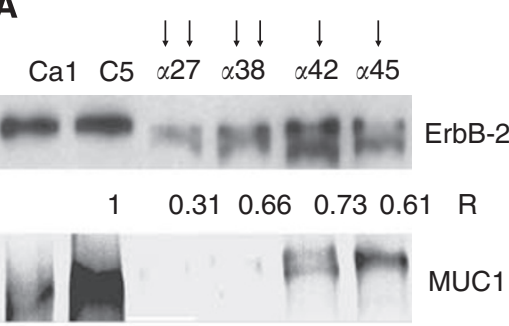

1 n.c. n.c. $0.250 .36 \quad R$

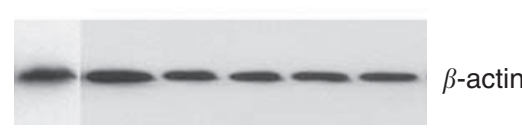

B

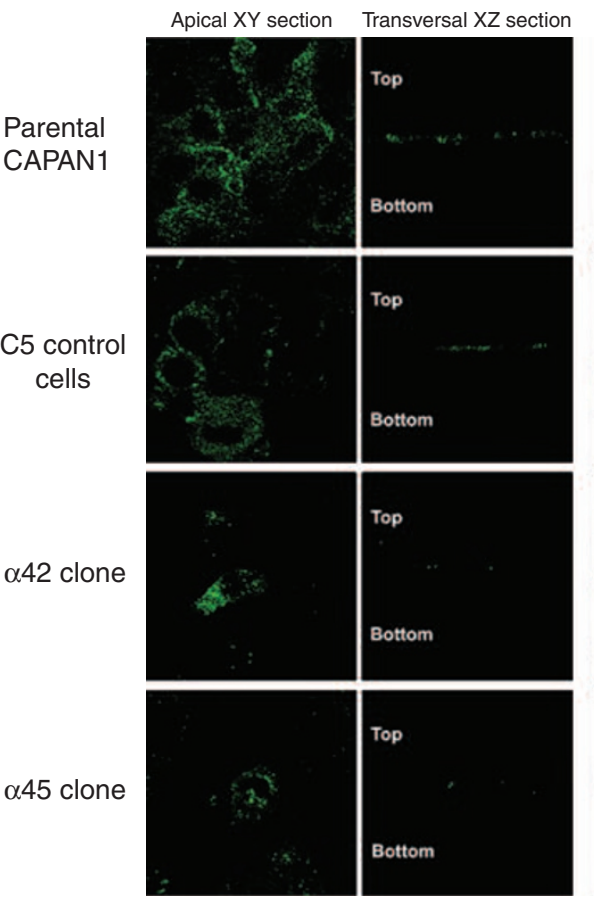

MUC4
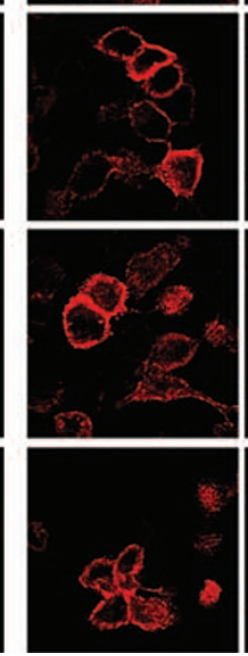

MUC1

Apical $X Y$ section Transversal $X Z$ section
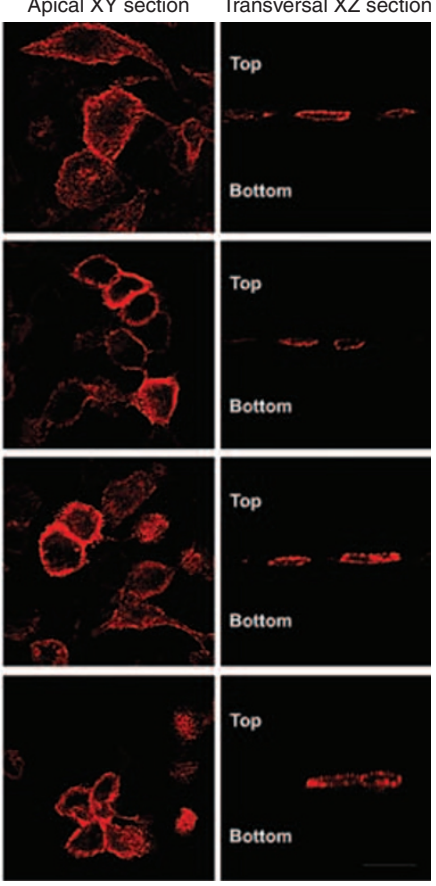

Figure I Expression pattern of MUCI membrane-bound mucin and ErbB-2 receptor in the CAPAN-I clones stably transfected with an AP-2 $\alpha$ expression vector ( $\alpha 27$ to $\alpha 45)$. (A) Western blot analysis of the expression of ErbB-2 and MUCI. One or two upper arrow(s) correspond to a low or high levels of expression of AP- $2 \alpha$, respectively. Bands were quantified by densitometry and a ratio (specific protein to $\beta$-actin) was calculated to evaluate differences between mock cells and the clones. Ratio values are indicated under each panel. Total cellular extracts were used. Cal, parental cell line; C5, mock cells. (B) Topography of MUCI and MUC4 expression was analysed by confocal microscopy. 
A

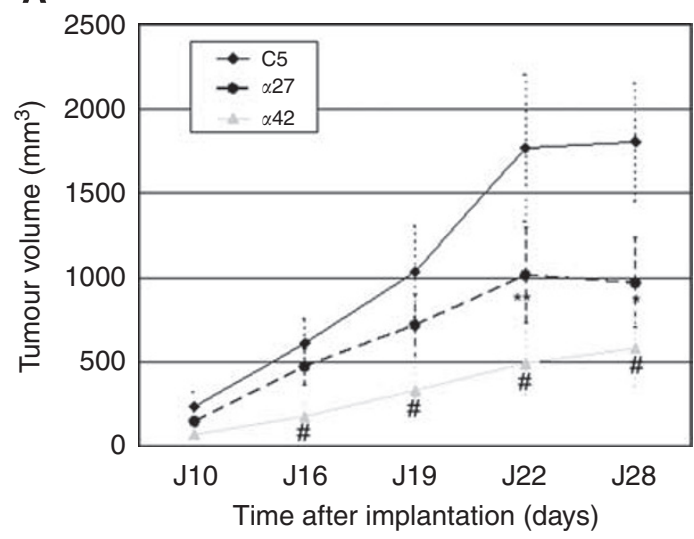

B $\quad$ C5 $\quad \alpha 27 \quad \alpha 42$

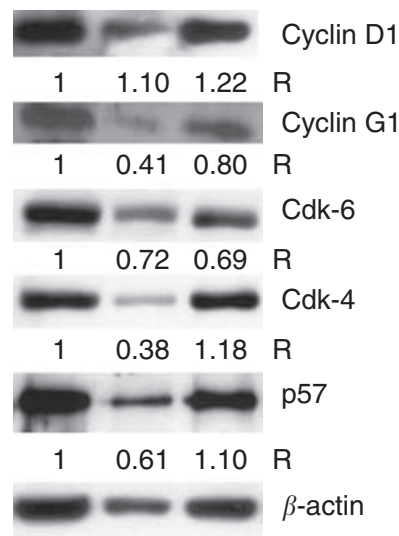

Figure 2 Effect of AP-2 $\alpha$ over expression on tumour growth and cell cycle. (A) In vivo tumour growth of mock CAPAN-I cells (C5 control clone), and of two clones overexpressing AP- $2 \alpha$ s.c. xenografted in athymic female nude mice ( $n=6$ per group). Tumours were measured every $3-6$ days and tumour volume was calculated (see Materials and Methods section for further details). Data are shown as mean (points) \pm s.d. (error bars). *,$P<0.05$; **, $P<0.0$ I; $\#, P<0.00$ I. (B) Expression levels of regulators of the cell cycle were evaluated by western blotting in control C5, $\alpha 42$ and $\alpha 27$ clones. Bands were quantified by densitometry and a ratio (specific protein to $\beta$-actin) was calculated to evaluate differences between mock cells and the clones. Ratio values are indicated under each panel.

(Fauquette et al, 2007), AP- $2 \alpha$ overexpression is accompanied by a decrease of the expression levels of total ErbB-2 and MUC1 (Figure 1A). A nearly complete extinction of MUC1 was observed in clones expressing high levels of AP- $2 \alpha$. We further examined whether AP- $2 \alpha$ overexpression could affect the localisation of MUC4 and MUC1 using confocal microscopy analysis. In parental CAPAN-1 cells and in C5 control cells (mock cells), MUC4 was mostly localised at the apical surface, whereas MUC1 showed both apical and basolateral staining (Figure 1B). In $\alpha 42$ and $\alpha 45$ clones that still expressed membrane-bound mucins, MUC4 apical staining was strongly decreased, whereas MUC1 showed a slight decrease of the apical staining together with an enhancement of the basolateral staining.

\section{Xenografts of CAPAN-1 cellular clones overexpressing AP- $2 \alpha$ in nude mice}

Three stable clones derived from CAPAN-1 cell line were s.c. implanted in nude mice ( $n=6$ mice per group): $\alpha 27$ and $\alpha 42$ clones that stably overexpressed high and moderate levels of AP- $2 \alpha$ transcription factor, respectively, and the control C5 clone. As shown in Figure 2A, the tumour volume was significantly lower in animals xenografted with the $\alpha 27$ or $\alpha 42$ clones than in those with the C5 clone. At day 22, the mean volume was $1766 \pm 433 \mathrm{~mm}^{3}$ in controls $(n=6), 1014 \pm 280 \mathrm{~mm}^{3}$ in $\alpha 27(n=6 ; P<0.01 v s$ control clone) and $493 \pm 189 \mathrm{~mm}^{3}$ in $\alpha 42$ animals $(n=6 ; P<0.001$ vs control clone, $P<0.01 v s \alpha 27)$. On day 28 , the difference of growth was significant only between controls $(n=3)$ and $\alpha 42$ animals $(n=3 ; P<0.001)$.

\section{Analysis of the expression of cell cycle regulators in CAPAN-1-deriving clones}

As $\alpha 27$ and $\alpha 42$ clones differed in terms of in vivo cell growth, we decided to compare their transcriptome using oligoGEArrays focused on cell cycle regulators. Results are shown in Table 1. The $\alpha 27$ clone exhibited a pattern of expression suggesting an inhibition of the cell cycle progression from the G1 to $S$ phase (decrease of cyclin-D1 and cdk-6 mRNAs) and from the G2 to M phase (decrease of cyclin-G1 cyclin-A1 and cdk-5 protein partner mRNAs). Interestingly, the $\alpha 42$ clone exhibited a quite different pattern of expression characterised by an increase of $C D K N 1 B$ $\left(\mathrm{p} 27^{\mathrm{kip} 1}\right)$ and $C D K N 1 C\left(\mathrm{p} 57^{\mathrm{kip} 2}\right)$ mRNAs together with a down-
Table I Selected genes relative to the cell cycle control whose expression was modified by AP- $2 \alpha$ overexpression in CAPAN-I cell line in comparison with the control cells

\begin{tabular}{|c|c|c|c|}
\hline Symbol & Gene name & $\begin{array}{l}\alpha 27 \text { clonel } \\
\text { C5 clone }\end{array}$ & $\begin{array}{c}\alpha 42 \text { clonel } \\
\text { C5 clone }\end{array}$ \\
\hline CCNAI & Cyclin-AI & 0.31 & 1.57 \\
\hline CCNDI & Cyclin-DI & 0.05 & 0.14 \\
\hline CCNGI & Cyclin-GI & 0.39 & 1.36 \\
\hline CDK4 & Cyclin-dependant kinase 4 & 0.95 & 1.15 \\
\hline CDK6 & Cyclin-dependant kinase 6 & 0.49 & 3.70 \\
\hline CDK5RI & & 0.07 & 2.11 \\
\hline CDK5RAP3 & & 0.14 & 3.26 \\
\hline CDKNIA & p2 $1^{\text {cipl }}$ & 0.32 & 0.41 \\
\hline CDKNIB & $\mathrm{p} 27^{\mathrm{kip} /}$ & 0.88 & 1.67 \\
\hline CDKNIC & $\mathrm{p} 57^{\mathrm{kip} 2}$ & 0.05 & 2.28 \\
\hline
\end{tabular}

regulation of cyclin-D1 mRNA, suggesting a strong cell cycle arrest at the G1/S phase in these cells. We try to validate our microarray data by carrying out western blot analysis for several proteins. We thus confirmed a decrease of CDK-4, CDK-6, cyclin-G1 and p57 $7^{\text {kip2 }}$ in $\alpha 27$ clone and an increase of p5 $57^{\text {kip2 }}$ in $\alpha 42$ clone. Previously we showed that $\mathrm{p} 21^{\mathrm{cip} 1}$ and $\mathrm{p} 27^{\mathrm{kip} 1}$ protein levels were increased in $\alpha 42$ clone (Fauquette et al, 2007). However, we were unable to confirm a decrease of cyclin-D1 at the protein level in both clones.

\section{AP- $2 \alpha$ activates $\mathrm{p} 27^{\text {kip } 1}$ promoter}

We previously showed that AP- $2 \alpha$ overexpression led to an upregulation of $\mathrm{p} 27^{\mathrm{kip} 1}$ protein levels in pancreatic cancer cells (Fauquette et al, 2007). As $\mathrm{p} 27^{\mathrm{kip} 1}$ expression is regulated at transcriptional and post-transcriptional levels, we next wanted to determine whether AP- $2 \alpha$ could act at the promoter level. To do so, CAPAN-1 cells were transiently cotransfected with a series of three deletion mutants of $C D K N 1 B$ promoter (Figure $3 \mathrm{~A}$ ) along with an AP- $2 \alpha$ expression vector. As shown in Figure $3 B$, loss of the -3568 to -774 nucleotides in the $C D K N 1 B$ promoter did not affect AP- $2 \alpha$ effect that remained weak. Further deletion up to -549 nucleotides allowed AP- $2 \alpha$ to increase the luciferase activity of the CDKN1B promoter activity by 4.3 -fold, suggesting the presence of inhibitory cis elements in the upstream region. Interestingly the $-549 /-1$ 
A

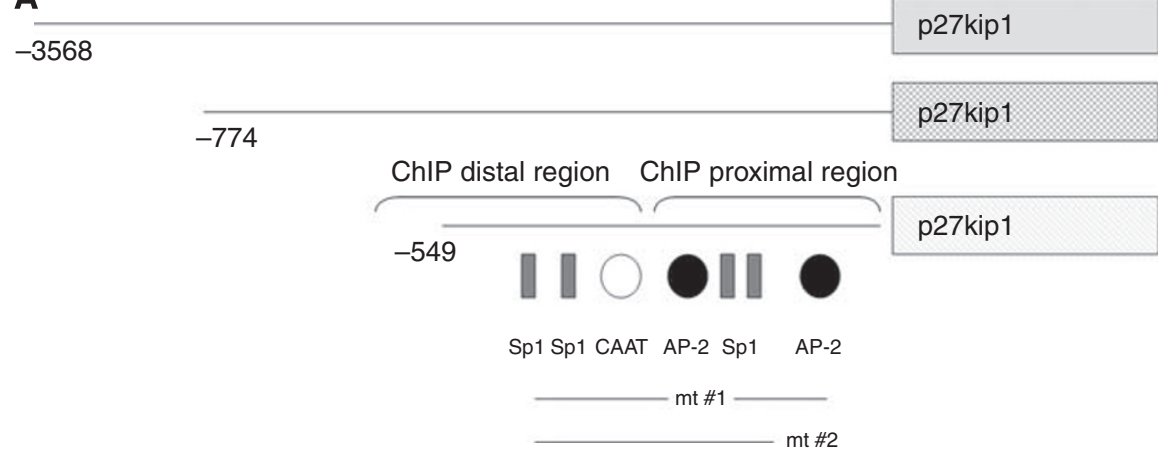

B

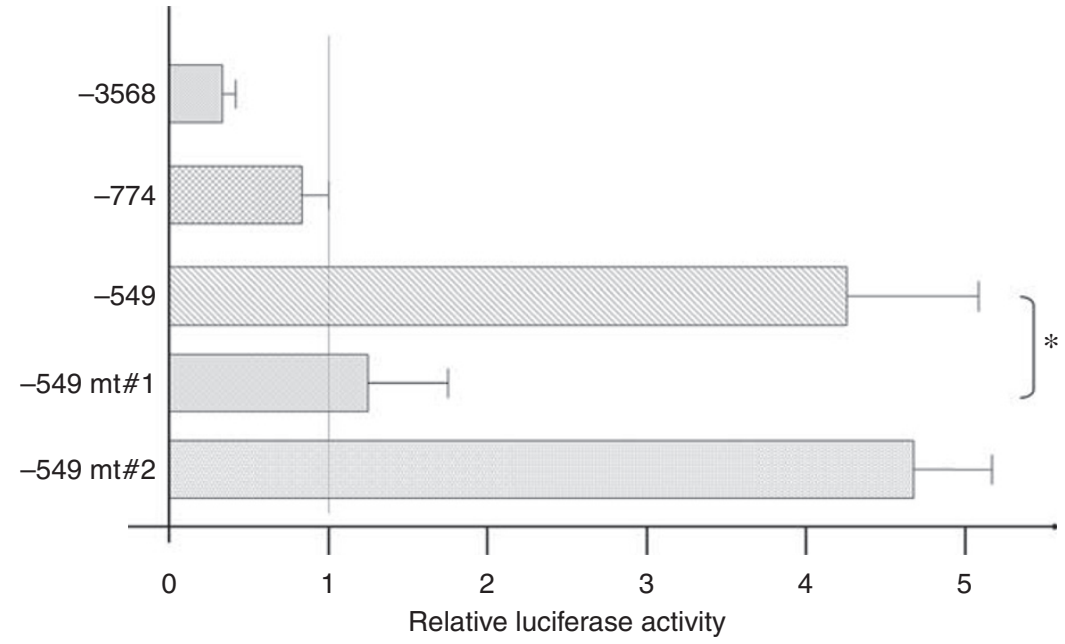

C

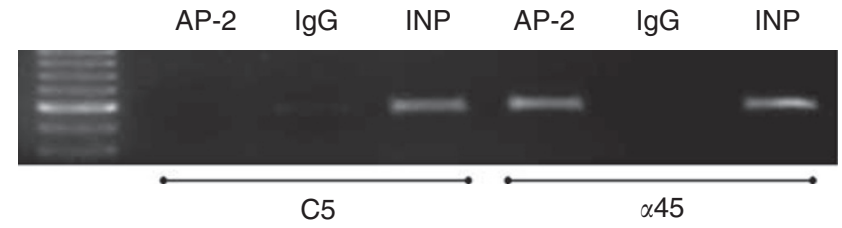

Figure 3 AP- $2 \alpha$ activates CDKNIB by direct interactions with its promoter. (A) Schematic representation of human CDKN IB promoter. The main cis elements for Spl, CAAT box-binding factor and AP-2 are shown. The location of the AP-2 cis elements that undergo site-directed mutagenesis is also shown. (B) The different CDKN IB promoter constructs were transiently cotransfected with $0.2 \mu \mathrm{g}$ of pRSV-AP- $2 \alpha$ or corresponding empty vector. Results are expressed as fold induction of luciferase activity relative to the empty expression vector (value was set at I.0). Values are means \pm s.d. for two independent experiments in which cotransfections were run in triplicate $(*, P<0.05)$. (C) ChIP assay. AP-2 represents the fraction precipitated with the antiAP- $2 \alpha$ antibody, IgG those precipitated with a normal rabbit lgG. PCR results obtained on the proximal region are shown.

region contains two putative binding sites for AP-2 located at -315 and -243 , and we decided to check their implication in AP- $2 \alpha$ effect by site-directed mutagenesis. Disruption of AP-2 site\#1 located at -315 led to a strong reduction of AP- $2 \alpha$ stimulatory effect $(P<0.05)$, whereas disruption of AP-2 site \#2 at -243 had no consequence. To decipher what happens in vivo, ChIP assay was carried out on two regions of $C D K N 1 B$ promoter, that is, a distal part $(-610 /-479)$ that did not contain the two AP-2 cis elements mentioned earlier and a proximal part $(-426 /-20)$ that did contain these elements. As expected, a strong binding of AP- $2 \alpha$ to the proximal part of $C D K N 1 B$ promoter was observed in the $\alpha 45$ clone that overexpressed the p27 protein (Figure $3 \mathrm{C}$ ).

\section{Effect of AP- $2 \alpha$ overexpression on gemcitabine sensitivity of pancreatic cancer cells}

As the expression level of AP- $2 \alpha$ was shown to determine the sensitivity of colon or breast cancer cell to chemotherapeutic drugs (Wajapeyee et al, 2005), we decided to evaluate whether
AP- $2 \alpha$ overexpression could affect the chemosensitivity of CAPAN-1 cells. A dose-dependent inhibition of cell proliferation was observed with gemcitabine for all the clones tested (Figure 4A). However, only the two clones that overexpressed moderate levels of AP- $2 \alpha(\alpha 42$ and $\alpha 45)$ exhibited a higher sensitivity to low concentrations of gemcitabine than the C5 control clone $(P<0.05)$. In contrast, the $\alpha 27$ and $\alpha 38$ clones, expressing high levels of AP- $2 \alpha$ and no MUC4, did not differ from control clone in terms of sensitivity to gemcitabine. Next, the effects of low doses of gemcitabine were further examined using flow cytometry. In absence of gemcitabine, the cell cycle profile of C5 control cells resembled that of $\alpha 27$ or $\alpha 42$ clones with $41.6 \pm 2.3,48.4 \pm 1.4$ and $43.4 \pm 2.7 \%$ in the $S$ phase, respectively (not shown). In contrast, after a 24 -h treatment with $0.1 \mu \mathrm{g} \mathrm{ml}^{-1}$ of gemcitabine, a strong cell cycle arrest in the G2 phase was observed in the $\alpha 42$ clone by comparison with C5 control clone $(P<0.05)$. A trend toward a cell cycle arrest in G1 occurred in $\alpha 27$ clone but remained nonsignificant (Figure 4B). Higher doses of gemcitabine $\left(1 \mu \mathrm{g} \mathrm{ml}^{-1}\right)$ led to a $\mathrm{G} 1$ phase synchronisation for all clones (not shown). 

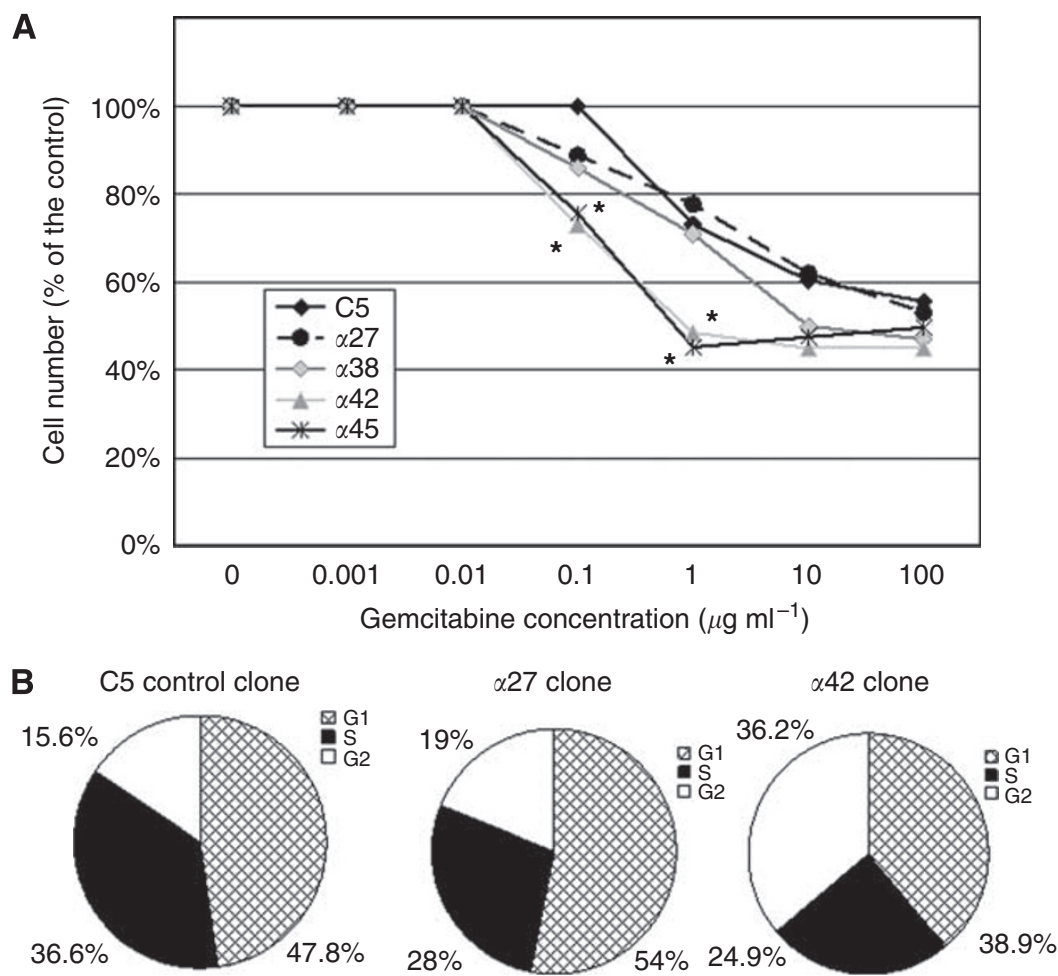

Figure 4 Effect of AP-2 $\alpha$ over expression on gemcitabine sensitivity of pancreatic cancer cells. (A) In vitro growth-inhibitory effect of gemcitabine against the mock CAPAN-I cells (C5) and the four clones that stably overexpressed AP-2 $\alpha$ transcription factor. Cell growth was assessed by cell counting of surviving cells. For each cell line, results are expressed as the percentage of surviving cells relative to the untreated cells that were arbitrarily given a I00\% value. Results are shown as mean of two independent experiments run in triplicate. *, $P<0.05$. (B) Cell cycle distribution profiles of $C 5$ control cells, $\alpha 27$ and $\alpha 42$ treated with $0.1 \mu \mathrm{g} \mathrm{ml}^{-1}$ of gemcitabine for $24 \mathrm{~h}$. The values are expressed as the mean of three independent experiments.

\section{Migration assay}

Previous studies conducted in our laboratory showed that stably overexpressed AP-2 $\alpha$ cells displayed a significant decrease of their invasion capacity in vitro (Fauquette et al, 2007). In this study, cell migration was evaluated using Boyden chambers. As shown in Figure 5, the number of migrating cells strongly decreases in all overexpressing AP- $2 \alpha$ cells clones compared with the C 5 control clone $(P<0.05$ for $\alpha 27$ and $P<0.001$ for $\alpha 38, \alpha 42$ and $\alpha 45$ vs control C5), suggesting that AP-2 $\alpha$ has a major role in migration properties of pancreatic cancer cells in vitro. Interestingly, $\alpha 42$ cells migrated less than $\alpha 27$ cells in vitro $(P<0.05)$ in accordance with their different behaviour in vivo (Figure $2 \mathrm{~A}$ ).

\section{DISCUSSION}

In a previous study we showed that AP- $2 \alpha$ expression concerned only $5.5 \%$ of human PDAC tissues, whereas it was expressed by nontumoural pancreatic ductal cells (Fauquette et al, 2007). We therefore hypothesised whether such a loss of expression of AP-2 $\alpha$, which is considered as a TSG in different tissues (Ruiz et al, 2001; Schwartz et al, 2007), could contribute to pancreatic carcinogenesis. To address this question, we took advantage of stable clones deriving from CAPAN-1 cells and overexpressing AP- $2 \alpha$ that we previously generated (Fauquette et al, 2007).

In this study, we found that a moderate overexpression of AP- $2 \alpha$ significantly inhibits pancreatic tumour growth in animal models. Our experimental data, together with recent results obtained on different cell lines (Orso et al, 2008), suggested that this antitumour activity resulted from a cell cycle arrest as we previously showed that the cyclin-dependent kinase inhibitor $\mathrm{p} 27^{\mathrm{kip} 1}$ protein levels in pancreatic cancer cells were strongly increased after an AP- $2 \alpha$ overexpression (Fauquette et al, 2007). Moreover, the

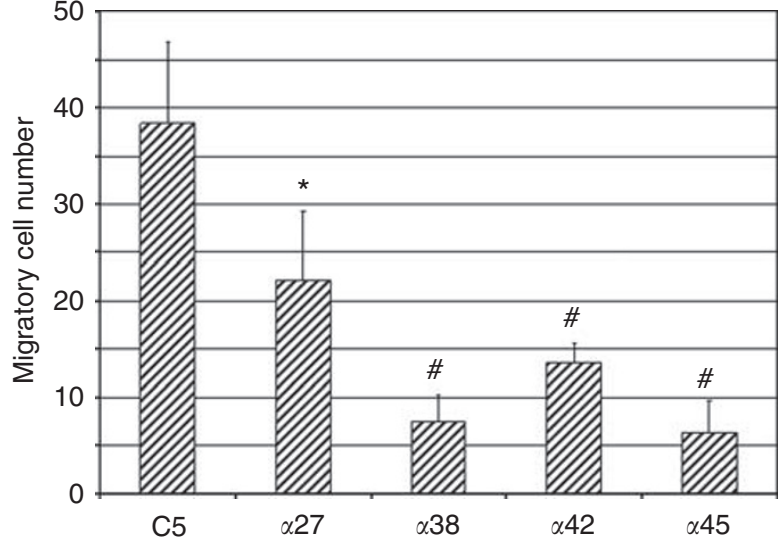

Figure 5 Migration assay. Migration properties of mock CAPAN-I cells (C5 control clone) and clones overexpressing AP- $2 \alpha(\alpha 27, \alpha 38, \alpha 42$ and $\alpha 45)$ were evaluated using Boyden chambers. Results are expressed as average migratory cell number per vision field (mean \pm s.e.m., *, $P<0.05$, $\#, P<0.001)$.

growth curves of the tumours deriving from the xenografted clones are inversely correlated to the $\mathrm{p} 27^{\mathrm{kip} 1}$ protein levels. We therefore decided to evaluate whether AP- $2 \alpha$ could regulate p $27^{\text {kip } 1}$ expression. Here we further showed that AP- $2 \alpha$ could induce $C D K N 1 B$ promoter activity directly by interacting with two proximal AP-2 cis elements located at -316 and -244 . Interestingly, the same proximal region of $C D K N 1 B$ promoter was recently shown to contain three cis elements for KLF4 transcription factor close to the AP-2 sites and to be induded by KLF4 in pancreatic 
cancer cell lines (Wei et al, 2008). Moreover, KLF4 overexpression led to a suppression of tumour cell growth both in vitro and in vivo, as shown for AP- $2 \alpha$. Whether AP- $2 \alpha$ and KLF4 could cooperate on $C D K N 1 B$ proximal promoter remains to be defined.

We next try to further document the impact of AP- $2 \alpha$ on the cell cycle regulators. Microarray analysis and western blotting allowed us to distinguish changes in gene expression linked to AP- $2 \alpha$ overexpression that were independent (observed in $\alpha 27$ clone) or dependent of MUC4 expression (only seen in $\alpha 42$ clone). In absence of membrane-bound mucins, AP- $2 \alpha$ represses the expression of the CDK- 4 and CDK- 6 that are activated during the G1 phase of the cell cycle (Malumbres and Barbacid, 2009) in presence of their protein partner (cyclin D). These variations are expected to promote a G1 phase arrest in $\alpha 27$ clone. Decrease of CDK- 4 seems of special interest as its constitutive activation in a mice model results in epithelial tumours affecting the gut, liver and digestive exocrine glands (Sotillo et al, 2001). CDK-4 thus has a central role in epithelial proliferation control. In contrast, MUC4 expression reverses the AP- $2 \alpha$-induced CDK- 4 decrease but, in the same time, is associated with an upregulation of the CDK-I p27 $7^{\mathrm{kip} 1}$, p $57^{\mathrm{kip} 2}$ and $\mathrm{p} 21^{\mathrm{cip} 1}$ (Fauquette et $\left.a l, 2007\right)$. We therefore speculate that MUC4 could trigger the G1 phase arrest initiated by AP- $2 \alpha$ overexpression. This result was expected in light of previous data showing that the rat Muc4 interacts with ErbB-2 receptor, that is expressed in $\alpha 42$ clone, and induces p $27^{\text {kip } 1}$ expression (Jepson et al, 2002).

We also showed that a moderate overexpression of AP- $2 \alpha$ in CAPAN-1 cells resulted in an increase of the chemosensitivity to low doses of gemcitabine. This original result, potentially relevant for pancreatic cancer therapy in which gemcitabine is the first-line treatment, was however expected as AP- $2 \alpha$ was previously shown to increase colon cancer cell sensitivity to chemotherapy. This effect was independent of p53 (Wajapeyee et al, 2005) and resulted from a downregulation of Bcl-2 and an induction of apoptosis (Wajapeyee et al, 2006). Moreover, the same group also showed that AP-2 was induced by a post-transcriptional mechanism by various chemotherapeutic agents such as adriamycin or cisplatin.

\section{REFERENCES}

Bosher JM, Totty NF, Hsuan JH, Williams T, Hurst HC (1996) A family of AP-2 proteins regulates c-erbB-2 expression in mammary carcinoma. Oncogene 13: $1701-1707$

Chaturvedi P, Singh AP, Chakraborty S, Chauhan SC, Bafna S, Meza JL, Singh PK, Hollingsworth MA, Mehta PP, Batra SK (2008) MUC4 mucin interacts with and stabilizes the HER2 oncoprotein in human pancreatic cancer cells. Cancer Res 68: 2065-2070

Chaturvedi P, Singh AP, Moniaux N, Senapati S, Chakraborty S, Meza JL, Batra SK (2007) MUC4 mucin potentiates tumor cell proliferation, survival, and invasive properties and interferes with its interaction to extracellular matrix proteins. Mol Cancer Res 5: 309-320

Chua YJ, Cunningham D (2006) Chemotherapy for advanced pancreatic cancer. Best Pract Res Clin Gastroenterol 20: 327-348

Eckert D, Buhl S, Weber S, Jäger R, Schorle H (2005) The AP-2 family of transcription factors. Genome Biol 6: 246

Fauquette V, Aubert S, Groux-Degrotte S, Hemon B, Porchet N, Van Seuningen I, Pigny P (2007) Transcription factor AP- $2 \alpha$ represses both the mucin MUC4 expression and pancreatic cancer cell proliferation. Carcinogenesis 28: 2305-2312

Fauquette V, Perrais M, Cerulis S, Jonckheere N, Ducourouble MP, Aubert JP, Pigny P, Van Seuningen I (2005) The antagonist regulation of the human MUC4 and ErbB-2 genes by the Ets protein PEA3 in pancreatic cancer cells: implications for the proliferation/differentiation balance in the cells. Biochem J 386: 35-45

Fischer C, Sanchez-Ruderisch H, Welzel M, Wiedenmann B, Sakai T, André S, Gabius H-J, Khachigian L, Detjen KM, Rosewicz S (2005) Galectin-1 interacts with the $\alpha 5 \beta 1$ fibronectin receptor to restrict carcinoma cell growth via induction of p21 and p27. J Biol Chem 280: $37266-37277$
However, no data are currently available in the literature to support such an effect for gemcitabine.

Another question to address is whether the decrease of MUC1 and MUC4 expression could contribute to the AP- $2 \alpha$-induced sensitisation of pancreatic cancer cells to gemcitabine. Indeed, recent studies showed that MUC1 overexpression in carcinoma cells increases their refractoriness to chemotherapeutic druginduced apoptosis (Ren et al, 2004; Kalra and Campbell, 2007). Accordingly, knockdown of MUC1 sensitises thyroid cancer cells to doxorubicine through activation of the intrinsic apoptotic pathway (Siragusa et al, 2007). Concerning MUC4, its silencing by shRNA in the pancreatic CD18-HPAF cell line led to a significant increase of apoptosis and to an induction of apoptosis mediators, such as caspase-2, caspase- 3 and caspase-7, and a repression of the anti-apoptotic protein S100A4 (Chaturverdi et al, 2007). However, there is no report in the literature showing that MUC4 silencing could enhance the cytotoxic action of chemotherapeutic drugs such as gemcitabine. Therefore, we speculate that in our cellular model, a slight decrease of MUC4 expression could potentiate AP$2 \alpha$ pro-apoptotic effect. On the opposite, a complete extinction of MUC4 expression seems unfavourable in terms of sensitivity to gemcitabine.

In conclusion, our results suggested that AP- $2 \alpha$ overexpression could be exploited to decrease the in vivo tumour growth of pancreatic cancer cells and probably to increase their sensitivity to conventional chemotherapy.

\section{ACKNOWLEDGEMENTS}

We thank Dr Tony Lovecchio for his help in the elaboration of the PCR of the CDKN1B promoter, and the IFR 114 for providing us imaging facilities and for flow cytometry analysis ( $\mathrm{N}$ Jouy). Dr Nicolas Jonckheere is a recipient of a postdoctoral fellowship from the Institut National du Cancer, France. Our research group is supported by grants from la Ligue Nationale contre le Cancer (Equipe Labellisée Ligue 2008).
Giovannetti E, Mey V, Danesi R, Mosca I, Del Tacca M (2004) Synergistic cytotoxicity and pharmacogenetics of gemcitabine and pemetrexed combination in pancreatic cancer cell lines. Clin Cancer Res 10: $2936-2943$

Jepson S, Komatsu M, Haq B, Arango ME, Huang D, Carothers Carraway CA, Carraway KL (2002) MUC4/sialomucin complex, the intramembrane ErbB2 ligand, induces specific phosphorylation of ErbB2 and enhances expression of p27kip1, but does not activate mitogen-activated kinase or protein kinase B/Akt pathways. Oncogene 21: 7524-7532

Kalra AV, Campbell RB (2007) Mucin impedes cytotoxic effect of 5-FU against growth of human pancreatic cancer cells: overcoming cellular barriers for therapeutic gain. Br J Cancer 97: 910-918

Malumbres M, Barbacid M (2009) Cell cycle, CDKs and cancer: a changing paradigm. Nat Rev Cancer 9: 153-166

Orso F, Penna E, Cimino D, Astanina E, Maione F, Valdembri D, Giraudo E, Serini G, Sismondi P, De Bortoli M, Taverna D (2008) AP- $2 \alpha$ and AP- $2 \gamma$ regulate tumor progression via specific programs. FASEB J 22: 2704-2714

Perrais M, Pigny P, Ducourouble MP, Petitprez D, Porchet N, Aubert JP, Van Seuningen I (2001) Characterisation of human mucin gene MUC4 promoter: importance of growth factors and proinflammatory cytokines for its regulation in pancreatic cancer cells. J Biol Chem 276: $30923-30933$

Ren J, Agata N, Chen D, Li Y, Yu WH, Huang L, Raina D, Chen W, Kharbanda S, Kufe D (2004) Human MUC1 carcinoma-associated protein confers resistance to genotoxic anticancer agents. Cancer Cell 5: $163-175$

Ruiz M, Troncoso P, Bruns C, Bar-Eli M (2001) AP-2 $\alpha$ transcription factor expression is associated with luminal differentiation and is lost in prostate cancer. Clin Cancer Res 7: 4086-4095 
Schneider G, Siveke JT, Eckel F, Schmid RM (2005) Pancreatic cancer: basic and clinical aspects. Gastroenterology 128: 1606-1625

Schwartz B, Melnikova VO, Tellez C, Mourad-Zeidan A, Blehm K, Zhao YJ, McCarty M, Adam L, Bar-Eli M (2007) Loss of AP- $2 \alpha$ results in deregulation of E-cadherin and MMP-9 and an increase of tumorigenicity of colon cancer cells in vivo. Oncogene 14: 4049-4058

Siragusa M, Zerilli M, Iovino F, Giovanna Francipane M, Lombardo $Y$, Ricci-Vitiani L, Di Gesu G, Todaro M, De Maria R, Stassi G (2007) MUC1 oncoprotein promotes refractoriness to chemotherapy in thyroid cancer cells. Cancer Res 67: 5522-5530

Sotillo R, Dubus P, Martin J, de la Cueva E, Ortega S, Malumbres M, Barbacid M (2001) Wide spectrum of tumors in knock-in mice carrying a Cdk4 protein insensitive to INK4 inhibitors. EMBO J 20: 6637-6647

Swartz MJ, Batra SK, Varshney GC, Hollingsworth MA, Yeo CJ, Cameron JL, Wilentz RE, Hruban RH, Argani P (2002) MUC4 expression increases progressively in pancreatic intraepithelial neoplasia. Am J Clin Pathol 117: $791-796$
Tellez C, McCarty M, Ruiz M, Bar-Eli M (2003) Loss of AP- $2 \alpha$ results in overexpression of protease-activated receptor-1 and correlates with the malignant phenotype of human melanoma. J Biol Chem 278: $46632-46642$

Vernimmen D, Gueders M, Pisvin S, Delvenne P, Winkler R (2003) Different mechanisms are implicated in ERBB2 gene overexpression in breast and other cancers. Br J Cancer 89: 899-906

Wajapeyee N, Britto R, Ravishankar HM, Somasundaram K (2006) Apoptosis induction by AP- $2 \alpha$ involves transcriptional repression of Bcl-2. J Biol Chem 281: 16207-16219

Wajapeyee N, Ganpat Raut C, Somasundaram K (2005) AP- $2 \alpha$ status determines the chemosensitivity of cancer cells: implications in cancer chemotherapy. Cancer Res 65: 8628-8634

Wei D, Kanai M, Jia Z, Le X, Xie K (2008) Kruppel-like factor 4 induces p27kip1 expression in and suppresses the growth and metastasis of human pancreatic cancer cells. Cancer Res 68: $4631-4639$ 